\title{
Somogy megye díszbogarai (Coleoptera: Buprestidae)
}

\author{
Muskovits József
}

Muskoviтs J.: The jewel beetles of Somogy county (Coleoptera: Buprestidae)

Abstract: An annotated list of jewel beetle species collected in Somogy county (Southern Hungary) and the relevant literature are presented. The oldest collected specimens date back to about 1875. Of the 119 species known to occur in Hungary, 82 are recorded from the area investigated. Palmar festiva (Linnaeus, 1767) is new to the Hungarian fauna.

\section{Bevezetés}

A díszbogarak (Buprestidae Eschscholtz, 1829) a Buprestoidea családsorozat egyetlen családját alkotják. Gyakran feltúnóen színpompás, jellegzetes alakú bogarak. A család tudományos elnevezését LiNNAEUS 1758-ban vezette be a rovartanba.

A díszbogarak családja a nyolcadik legnépesebb a bogarak között, az egész Földön hozzávetôlegesen 15 000, a Kárpát-medencében mintegy 170, Magyarországon 119 faj fordul elő. Nagyságuk változó, a hazai legnagyobb díszbogár, a Chalcophora mariana elérheti a $32 \mathrm{~mm}$ hosszúságot, a legkisebb Trachys fajok alig haladják meg a $2 \mathrm{~mm}$-t.

Jelen összeállításban Somogy megye díszbogár-faunáját dolgozom fel. Ehhez az adott ösztönzést, hogy az elmúlt években alkalmam volt hazánk szinte valamennyi természettudományi múzeumi rovargyưjteményének és a jelentósebb magángyújtemények díszbogarait determinálni, illetve a régebbi meghatározásokat szükség esetén revideálni.

\section{A kutatások rövid ismertetése}

A Magyar Természettudományi Múzeum állattárában Somogy megye területéról már 125 évvel ezelőtt gyújtött díszbogarakat is találunk. A megye rovarfaunájának elsố ismertebb gyújtôje a múlt század utolsó harmadában Lichtneckert Ferenc volt Siófokon. Jelentôs gyújteménye a Magyar Természettudományi Múzeum Állattárába került. Sajnos, az általa gyújtött és preparált bogarak identifikációs cédulái a mai minimális követelményeknek sem felelnek meg, mivel rajtuk csak a "Siófok, Lichtneckert” felirat található, minden egyéb tájékoztató adat hiányzik, és sokszor még az sem biztos, hogy az illetô példány valóban Siófokon került elö.

A századforduló másik jelentôs gyúitôje Ehmann Ferenc, aki az 1896-191 1 közötti években rendszeresen gyújtött Öszöd (ma Balatonöszöd) területén.

Az első világháború eloótt Somogy vármegye területén a többi gyújtô - Hajós József, Kanabé Dezső, Peregi Imre - csak alkalomszerúen gyújtött, legalábbis kevés példány maradt meg a gyújteményekben. 
A két világháború közötti idóben is csak alkalmi gyúitések voltak, és szintén kevés példány került a gyúiteményekbe (Apt Ödön, Stiller Viktor).

A második világháború után eléggé nehezen indultak meg a gyújtések. 1955ben Dr. Lenci (Lenczy) Rudolf gyújtött eredményesen a Baláta-tónál. Ennek a korszaknak vitathatatlanul legjelentősebb gyúitője Nattán Miklós volt, aki 1958-1968 között sokat gyứjtött Kaposvár környékén. Elsősorban lepkész volt, de bogarakat is szép számmal gyújtött.

A fent említett személyek által létrehozott gyújtemények nagyobbrészt a Magyar Természettudományi Múzeum bogárgyúuteményébe kerültek.

Az 1980-as 90-es években években megszaporodott a gyúitók száma. Név szerint megemlítem Sár József-et és Horvatovich Sándor-t, akik rendszeresen kutatták a védett területek rovarvilágát. Az utóbbi években Ábrahám Levente, Ádám László, Merkl Ottó, Rozner György folytatott említésre méltó díszbogár gyújtéseket is.

A jelentősebb amatőr rovarászok közül Bessenyi Ferenc, Gaskó Kálmán, Dr. Ilniczky Sándor, Juhász János Csaba, Kondorosy Elôd, Dr. Medvegy Mihály, Muskovics András, Dr. Muskovits József, Podlussány Atilla, Rahmé Nikola, Retezár Imre, Rozner István, Dr. Somorjai Gyula, Szalóki Dezső és Székely Kálmán nevét kell megemlíteni, akik Somogy megye területén több-kevesebb rendszerességgel díszbogarakat is gyújtöttek.

A Magyar Rovartani Társaság 1999-ben a Duna-Dráva Nemzeti Park területére szervezett sikeres kirándulást, amelynek hatására megnövekedett az amatôr rovarászok - közöttük a kifejezetten díszbogarakra specializálódottaké is tevékenysége, és talán ennek lehet az eredménye hazánk területére egy új díszbogárfaj, a Palmar festiva kimutatása.

A megnövekedett gyújtókedv azt eredményezte, hogy Somogy megyét a jobban megkutatott megyéink közé sorolhatjuk. Legjobban kutatottak a Balatonhoz közeli területek, a Barcsi borókás, Kaposvár környéke és a Boronka-melléki Tájvédelmi Körzet, de azért vannak még jelentôs területek, amelyek nincsenek kellóképpen kikutatva, legalábbis a díszbogarakat illetően.

A Somogy megyében gyújtött díszbogarakra vonatkozó irodalmi közleményeket a következókben ismertetem.

KuTHy (1986) „A Magyar Birodalom Állatvilága” c. müvében mindössze egyetlen fajra, az Acmaeoderella flavofasciata-ra találunk egy lelóhely-adatot „P.Vadé" néven, ami feltételezésem szerint a mai Vadépusztá-val azonosítható.

Csiki (1909-1915): „Magyarország díszbogarai” c. munkájában elsôsorban határozókulcsot közöl és csak kevés lelóhelyadatot, így nem meglepó, hogy Somogy megyét illetóen csak 3 faj 3 lelóhelyadata található meg benne.

KAsz^B (1940) kifejezetten lelóhely-adatokat közló múve már lényegesen több adatot tartalmaz, nevezetesen 38 faj 53 lelóhelyét. Érdekességként megemlítem, hogy a fajlista összeállításánál Lichtneckert adatait nem vette figyelembe és fóként Ehmann gyújtései növelték meg a fajok számát.

SÁr (1992) a Boronka-melléki Tájvédelmi Körzet területén végzett rovartani gyứjtések összevont adatait közli és ebben 5 díszbogárfaj kerül megemlítésre. Az általa említett Chrysobothris chrysostigma újrahatározás után Chrysobothris affinis-nek bizonyult.

Merki (1998) a Duna-Dráva Nemzeti Park területéról negyvenhat bogárcsalád fajait ismerteti, közöttük Somogy megye területéról 14 díszbogárfajt említ meg.

A fenti ismertetésból látható, hogy összefoglaló adatközlés még nem készült, ezt a hiányosságot igyekszem most ebben az összeállításban pótolni. 


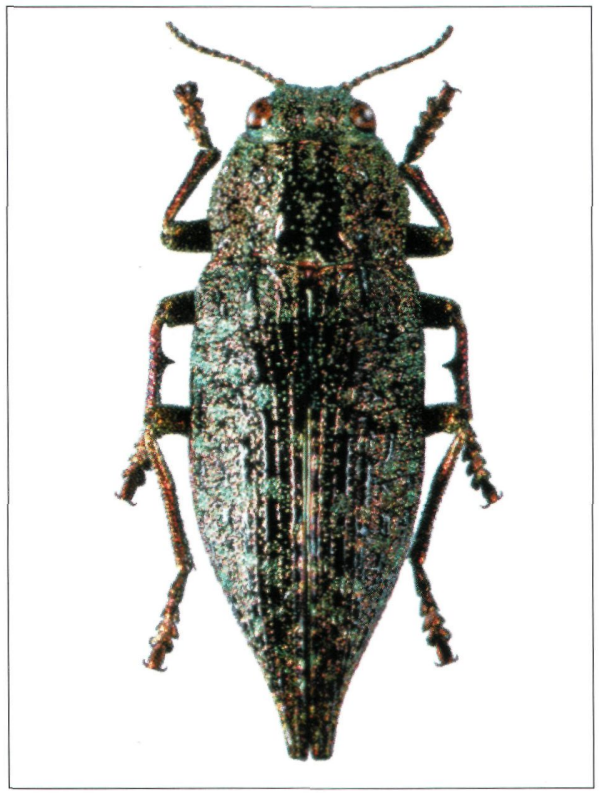

1. ábra: Dicerca furcata Fotó: Retezár I.

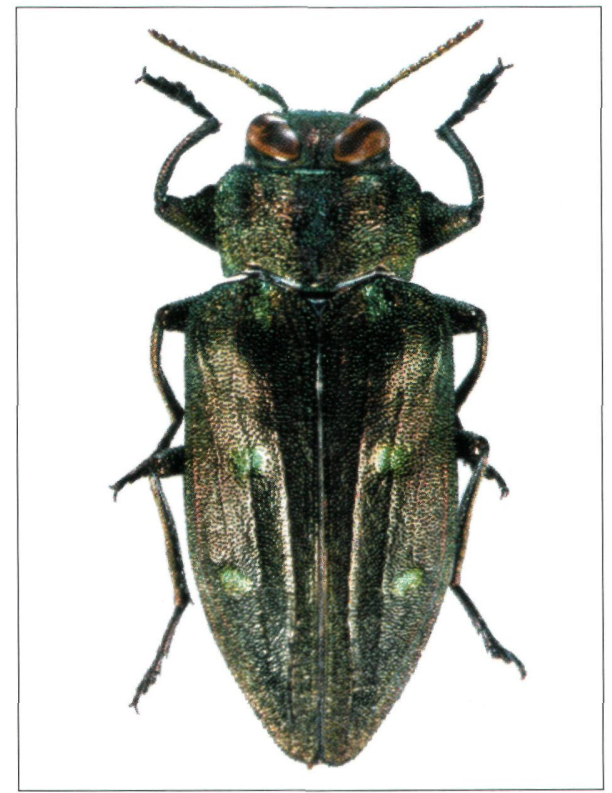

2. ábra: Chrysobothris affinis Fotó: Retezár I. 


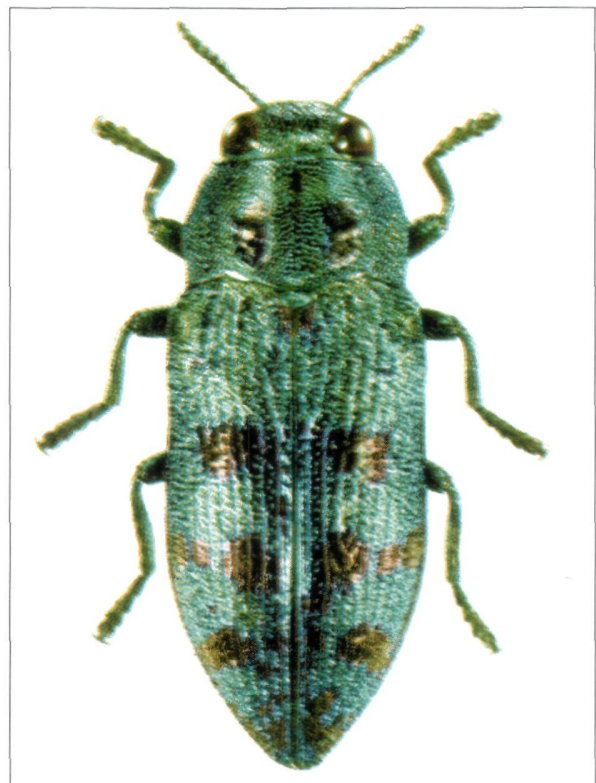

3. ábra: Palmar festiva Fotó: Retezár I.

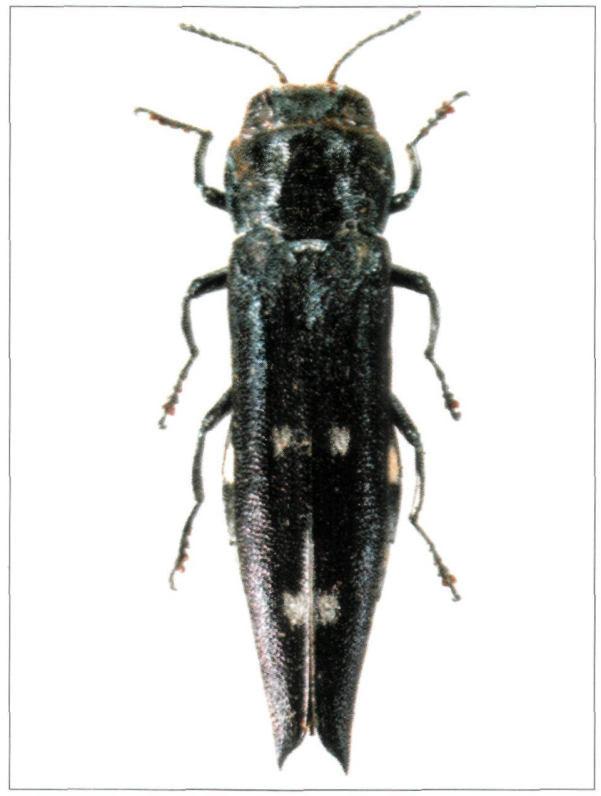

4. ábra: Agrilus guerini Fotó: Retezár I. 


\section{Somogyból ismert fajok jegyzéke}

Ptosima flaroguttata (Illiger, 1803) Holomediterrán elterjedésú faj, nálunk elterjedt, nem ritka, a lárvák sajmeggyben, szilvafában fejlödnck. - Kisberény, Zamárdi.

Acmaeodera (Acmaeotethya) degener (Scopoli, 1763) - Nyugat-palearktikus elterjedésú, a tölgyesekben sokfelé elóforduló, de nem gyakori faj.- Balatonboglár-Vadépuszta, Zamárdi.

Acmaeoderella (Carininota) flarofasciata (Piller \& Mitterpacher, 1783) - Nyugat-palearktikus elterjedésú, a tölgyesekben elterjedt, gyakori. - Balatonboglár, Balatonöszöd, Darány, Kaposvár, Köröshegy, Nagybajom, Siófok, Somogyszob, Újvárfalva.

Acmaeoderella (Carininota) mimonti (Boieldieu, 1865) - Kelet-mediterrán elterjedésú, clsốsorban a Duna-Tisza közötti homokos területcken fordul elö, somogy megyei, múlt századi elófordulását azóta sem sikerült újabb példánnyal megerôsíteni. - Balatonöszöd.

Sphenoptera (Chilostetha) parnula (Fabricius, 1798) - Holomediterrán elterjedésü, füves területcken szórványosan előforduló, ritka faj. Siófok.

Sphenoptera (Chilostetha) substriata Krynicki, 1834 - Közép- és kelet-mediterrán elterjedésú, füves területeken szórványosan elóforduló, ritkább faj. - Siófok.

Capnodis tenebrionis (Linnaeus, 1761) Holomediterrán elterjedésú, lárvája gyümölcsfákban él, sokfelé megtalálható, az utóbbi ćvtizedekben megritkult. - Balatonöszöd.

Aurigena lugubris (Fabricius, 1777) - Keletmediterrán elterjedésú, lárvája galagonyában, szilvafában, kökényben él, sokfelé megtalálható, az utóbbi évtizedekben megritkult. Balatonöszöd, Kaposvár, Siófok.

Dicerca alni (Fischer,

1824) -

Holomediterrán elterjedésú, lárvája égerfában él, šórványos elterjedésú, ritkább faj. - BarcsKözéprigóc, Darány, Kaposvár.

Dicerca berolinensis (Herbst, 1779) Euroszibériai elterjedésú, lárvája gyertyánban és bükkben él, sokfelé elöfordul, de nem közönséges. - Balatonboglár-Vadépuszta, Balatonöszöd, Kaposgyarmat, Kaposvár, Siófok, Somogyszob, Taszár.

Dicerca furcata (Thunberg, 1787) Euroszibériai elterjedésú, lárvája fenyốben él, nálunk rendkívül ritka. - Csurgó, Darány.

Dicerca (Argante) moesta (Fabricius, 1794) Nyugat-palcarktikus elterjedésú, Magyaror- szágról csak egy példányban került elö, valószínúleg fenyőfával behurcolt példány lehetett. Fonyód.

Poecilonota pariolosa (Paykull, 1799) Euroszibériai elterjedésú, a lárva nyárfákban él, szórványos előfordulású, ritka faj.Törökkoppány.

Lampra dipes Guillebeau, I889 - Nyugatpalearktikus elterjedésú, a füzesekben, égeresekben szórványosan elóforduló, ritkább faj. Balatonöszöd, Kaposvár, Vörs-Diás sziget.

Lampra mirifica Mulsant, 1855 Holomediterrán elterjedésú, lárvája szilfákban él, sokfelé elófordul, de nem közönséges. Balatonöszöd, Kaposvár, Siófok.

Lampra rutilans (Fabricius, 1777) - Nyugatpalearktikus elterjedésú, a hársfákon fordul elō, nem ritka. - Balatonöszöd, Kaposvár.

Palmar festiva (Linnaeus, 1767) Holomediterrán elterjedésú, lárvája borókában él, Magyarország faunájára új faj, amelynek elsó példánya csak 1999-ben került cló a Barcsi ősborókásból. - Darány.

Eurythyrea quercus (Herbst, 1780) Pontomediterrán elterjedésú faj, a tölgyesekben fordul clő és rendkívül ritka.- Balatonöszöd.

Buprestis heamorthoidalis Herbst, 1780 Nyugat-palcarktikus elterjedésú, à ôshonos és a telepítet fenyvesekben sokfelé eloofordul, gyakori. - Balatonboglár, Balatonöszöd, Barcs, Barcs-Középrigóc, Kaposvár, Nagybajom, Siófok.

Buprestis octoguttata Linnaeus, 1758 Euroszibériai elterjedésû́, fenyőfélékben éló faj, amely eddig csak a Dunántúlról került eló, és rendkívül ritka. - Balatonöszöd.

Trachypteris picta decastigma (Fabricius, 1787) - Holomediterrán eltcrjedésú, a nyárfásokben helyenként gyakori faj. Balatonfenyves, Kaposvár, Siófok.

Phaenops cyanea (Fabricius, 1775) Euroszibériai elterjedésú, fenyőfélékben élő faj, amely elterjedt, gyakori. - Barcs, Kaposvár, Nagybajom, Siófok, Somogyszob, Újvárfalva.

Anthaxia candens (Panzer, 1789) - Nyugatpalearktikus elterjedésú, feltúnően szép faj, lárvája sajmeggyben. cseresznyefában él, elterjedt, de nem túl gyakori. - Siófok.

Anthaxia deaurata (Gmelin, 1788) Mediterrán-kaszpi elterjedésú, szilfákon található meglehetôsen ritka faj. - Balatonendréd, Kaposvár, Siófok. 
Anthaxia fulgurans (Schrank, 1789). Nyugat-palearktikus elterjedésú, a tölgyesekben elterjedt, gyakori. - Babócsa, Balatonföldvár, Balatonöszöd, Heresznye, Kaposvár, Látrány, Potony, Siófok, Somogyszob.

Anthaxia funerula (Illiger, 1803) . Holomediterrán elterjedésú, lárvája seprôzanóban és rekettyében él, szórványosan elöforduló, ritkább faj. - Balatonendréd, Balatonszéplak, Siófok, Somogyszob.

Anthaxia manca (Linnaeus, 1767) . Euroszibériai elterjedésû́, a szilfákon helyenként gyakori. - Balatonföldvár, Kaposvár, Tótújfalu.

Anthaxia nitidula nitidula (Linnaeus, 1758). Nyugat-meditcrán elterjedćsú, mindenfelé elterjedı, külonféle virágokon, elsősorban vadrózsán gyakori. - Balatonföldvár, Balatonöszöd, Balatonszemes, Barcs-Középrigóc, BószénfaRopoly-puszta, Gyćkényes, Kaposfüred, Kaposvár, Kisberény, Öreglak, Órtilos, Somogyszob-Baláta-tó, Somogyudvarhely, Újvárfalva, Zamárdi.

Anthaxia nitidula signaticollis Krynicki, 1832 Kelet-mediterrán elterjedésü, a keleti országrészben elterjedt, különféle virágokon, elsôsorban vadrózsán gyakori, a Dunántúlon jóval ritkább. - Siófok.

Anthaxia podolica Mannerheim, 1837 . Nyugat-palearktikus elterjedésú, a tölgyesekben elterjedt, nagyon gyakori - Balatonendréd, Balatonföldvár, Balatonöszöd, Barcs, Csurgó, Kaposvár, Potony, Siófok.

Anthaxia salicis (Fabricius, 1777). Holomeditcrrán elterjedésú, leginkább a hegy . és dombvidékeken fordul elō, ahol helyenként gyakori - Balatonöszöd, Bószénfa-Ropolypuszta, Csurgó, Kaposvár.

Anthaxia semicuprea Küster, 1850 - Nyugatpalearktikus elterjedésú, a hegy- és dombvidékeken szórványosan elóforduló, ritkább faj. Balatonöszöd, Kaposvár, Siófok.

Anthaxia (Haplanthaxia) cichorii (Olivier, 1790) - Holomediterrán elterjedésú, clsősorban ernyösvirágokon helyenként gyakori. Balatonberény, Balatonöszöd, Kaposvár, Siófok.

Anthaxia (Haplanthaxia) millefolii (Fabricius, 1801) - Kelet-mediterrán elterjedésú, a melegebl) fekvésü tölgyesekben virágokon helyenként gyakori. - Balatonöszöd, Siófok.

Anthaxia (Haplanthaxia) olympica Kiesenwetter, 1880 - Pontomediterrán elterjedésú faj, clhagyout gyümölcsösökben helyenként nemiratka. - Siófok, Újvárfalva, Zamárdi.
Anthaxia (Melanthaxia) godeti Castchau \& Gory, 1839 - Holomeditcrán clterjedésú, az alacsonyabb vidékek ültetett fenyveseiben eltexjedt, gyakori. - Balatonöszöd, BaresKözéprigóc, Bélavár, Darány, Lengyelóti, Nagybajom, Somogyszob, Újvárfalva.

Anthaxia (Melanthaxia) helvetica Sticrlin, 1868 - Mediterrán elterjedésú faj, a Dunántúl nyugati fenyveseiben nem ritka. - Zamárdi.

Anthaxia (Melanthaxia) istriana Rosenhauer, 1847 - Mediterrán elterjedésú faj, amely fóként a Balaton környéki borókásokban fordul cló, ritka. - Balatonendréd, Darány, Koppány, Zamárdi.

Anthaxia (Melanthaxia) nigrojubata incognita Bíly, 1986 - Pontomeditcrán elterjedésú alfaj, lárvája luc-és jegenyefenyóben él, nagyon ritka. - Siófok.

Anthaxia (Melanthaxia) quadripunctata (Limnacus, 1758) - Euroszibériai cluerjedésú, a fenyvesckben mindenfelé elterjedt, gyakori. Balatonendréd, Balatonöszöd, Barcs, BaresKözéprigóc, Darány, Kaposvár, Siófok, Somogyszob-Baláta-tó, Újvárfalva.

Chrysobothris affinis (Fabricius, 1794) Euroszibériai eltejedésú, a tölgyesckban mindenfelé elterjedt, gyakori. - Balatonöszöd, Darány, Gyugy, Hács, Iharosberény, Kaposvár, Nagybajom, Somogyszob-Baláta-tó, Zamárdi.

Coraebus elatus (Fabricius, 1787) Pontomediterrán elterjedésú, sokfelé clófordul, vérfún és apróbojtorjánon helyenként gyakori. - Balatonöszöd, Barcs-Középrigóc, Gyékényes, Siófok.

Coraebus florentinus (Herbst, 1801) Holomediterrán elterjedésứ, a tölgyesekben gyakori, ennek ellenére életmódja miatt - rendszerint magasan, a tápnövény koronájában tartózkodik - ritkán kerüll a gyúiłtók szeme elé. Törökkoppány.

Coraebus rubi (Linnacus, 1767) l’alearktikus elterjedésú faj, a hamvasszedren helyenként gyakori. - Balatonöszöd, Siófok.

Nalanda fulgidicollis (Lucas, 1846) Holomediterrán elterjedésú, a tölgyesekben és füzesckben szórványosan clőforduló, ritkább faj. - Balatonendréd.

Agrilus (Uragrilus) ater (Linnacus, 1767) Nyugat-palearktikus elterjedésü, a füzc'sekben és nyárfásokban helyenként nem ritka. . Babócsa, Törökkoppány.

Agrilus (Uragrilus) gruerini Lacordaire, 1835 Nyugat-palcarktikus elterjedésü, a füzesekben fordul clö, nálunk rendkívül ritka. Magyarországon eddig clókerült példányok - eggy kivéte- 
lívcl - a Dél-Dunántúl füzesciból kerültek cló. Barcs, Órtilos.

Agrilus albogularis Gory, 1841 - Euro-kaszpi cltcrjedésú faj, amelynek lárvái pusztai ürömben élnck. Leginkább az Alföldön fordul cló, a D)unántúlon ritkább. - Balatonlelle, Balatonöszöd, Siófok.

Agrilus angustulus (Illiger, 1803) Euroszibériai elterjedésú, a tölgyesekben a leggyakoribb Agrilus-faj. - Balatonöszöd, Barcs, Gyćkényes, Kaposvár, Nagybajom, Siófok, Taszár, Tótújfalu.

Agrilus auricollis Kiesenwetter, 1857 Pontomediterrán elterjedésú, szilfán és hársfán fordul eló, ritkább faj. - Bélavár, Kaposvár, Siófok.

Agrilus biguttatus (Fabricius, 1777) Euroszibériai elterjedésú faj, a tölgyesekben elterjedt, gyakori. - Balatonendréd, Balatonöszöd, Hács, Iharosberény, Kaposvár, Lipótfa, Siófok, Somogyszob-Baláta-tó, Zamárdi.

Agrilus cinctus (Olivier, 1790) - Atlantomediterrán elterjedésú, nálunk szórványos előfordulású, ritka faj. - Balatonöszöd, Siófok.

Agrilus convexicollis Redtenbacher, 1849 Nyugat-palearktikus elterjedésú, a kơrisfákon helyenként nem ritka. - Balatonfenyves, Balatonföldvár, Siófok.

Agrilus cuprescens Ménétriés, 1832 (= aurichalceus, Redtenbacher, 1849) Holomediterrán elterjedésú faj, a szederféléken és a vadrózsán helyenként nem ritka. Balatonföldvár, Kaposvár.

Agrilus cyanescens Ratzeburg, 1837. Euroszibériai elterjedésû, a loncféléken található, ritka faj. - Siófok.

Agrilus derasofasciatus Lacordaire, 1835 Holomediterrán elterjedésú faj, vadszólón vagy clvadult szólön helyenként nem ritka. - Kaposvár, Siófok, Somogyvár, Taszár.

Agrilus graminis Castelnau \& Gory, 1839 . Holomediterrán elterjedésú, a tölgyesekben nem ritka. - Balatonöszöd, Siófok.

Agrilus hastulifer Ratzeburg, 1839 Holomediterrán elterjedésú, a tölgyesekben nem ritka. - Balatonföldvár, Siófok.

Agrilus hyperici (Creutzer, 1789) - Nyugatpalearktikus elterjedésû, orbáncfüvön sokfelé clófordul, gyakori. - Balatonboglár, Balatonlelle, Balatonöszöd, Barcs, BarcsKözéprigóc, Bélavár, Darány, Kaposvár, Látrány, Siófok.

Agrilus laticonis (Illiger, 1803) - Nyugatpalcarktikus elterjedésú, a tölgyesekben nem ritka.- Balatonöszöd, Kaposvár.
Agrilus lineola Redtenbacher, 1849 Pontomediterrán elterjedésú, a füzesekben csak kevés helyról került elő, ritka. - Siófok.

Agrilus litura Kiesenwetter, 1857 . Holomediterrán elterjedésü faj, a tölgyesekben fordul eló, nem gyakori. - Siófok.

Agrilus obscuricollis Kiesenwetter, 1857 - Mediterrán elterjedésú, a tölgyesekben gyakon. Balatonendréd, Darány, Kaposvár, Siófok.

Agrilus olivicolor Kiesenwetter, 1857 Nyugat-palearktikus elterjedésú, a tölgyesekben gyakori. - Balatonendréd, Balatonfenyves, Balatonöszöd, Barcs, Kaposvár, Nagybajom, Siófok, Taszár.

Agrilus pratensis Ratzeburg, 1839 Euroszibériai clterjedésú faj, a nyárfásokban gyakori. - Balatonfenyves, Fonyód-Bélatelep, Kaposvár, Siófok.

Agrilus roscidus Kiesenwetler, 1857 Holomediterrán elterjedésú faj, amely bengeféléken nem ritka. - Darány, Kaposvár, Nagybajom, Siófok.

Agrilus salicis J. Frivaldszky, 1877 - Magyarországról leirt, pontomediterrán elterjedésú faj, amely az Alföldön helyenként gyakori, de a Dunántúlon, a füzesekben jóval ritkább. Balatonlelle, Siófok.

Agrilus sericans Kiesenwetter, 1857 - Keletmediterrán elterjedésú faj, amely az alföldi ürmös-pusztákon helyenként gyakori, a Dunántúlon ritka. - Siófok.

Agrilus sulcicollis Lacordaire, 1835 Euroszibériai elterjedésú faj, a tölgyesekben mindenfelé elterjedt, gyakori. - Balatonfenyves, Balatonföldvár, Balatonöszöd, Kaposvár, Péterhida, Siófok.

Agrilus piridis (Linnaeus, 1758) - Euroszibériai elterjedésú, nagyon változékony faj, amely a füzesekben, bükkösökben elterjedt, gyakori. - Barcs, Bélavár, Siófok, Taszár, Újvárfalva.

Paracylindromorphus subuliformis (Mannerheim, 1837) - Európai-közép-ázsiai elterjedésûi faj, amely a pusztafüves területeken helyenként gyakori. - Balatonfölvár, Balatonszárszó, Siófok.

Cylindromorphus filum (Gyllenhal, 1817) Nyugat-palearktikus elterjedésú, a füves, félszáraz területeken helyenként nagyon gyakori. Balatonfenyves, Balatonföldvár, Balatonlelle, Balatonöszöd, Barcs, Barcs-Középrigóc, Bélavár, Darány, Látrány, Siófok.

Aphanisticus elongatus Villa, 1835 Holomediterrán elterjedésú, a sásos, nedvesebb réteken szórványosan elóforduló, ritka faj. Siófok. 
Aphanisticus pusillus (Olivier, 1790) Holomeditcrrán elterjedésú, a szittyós, nedvesebb réteken szórványosan előforduló, ritkább faj. - Balatonlelle, Balatonöszöd, Istvándi.

Habroloma geranii Silfverberg, 1977 . Eurossibériai elterjedésú faj, ancly a piros gólyaorron helyenként gyakori. - Siófok.

Trachys minutus (Linnaeus, 1758) Euroszibériai elterjedésú faj, amelynck lárvái lombosfák leveleiben aknáznak. Sokfelé clőfordul, gyakori. - Babócsa, Balatonberény, Balatonendréd, Balatonfenyves, Balatonlelle, Balatonöszöd, Barcs, Bélavár, Darány, Heresznye, Kaposvár, Látrány, Örtilos, Siófok, Vízvár, Zamárdi.

Trachys problematicus Obenberger, 1916 Balkáni-közćp-curópai előfordulású faj, amely tisztesfüvön helyenként nem ritka. Balatonendréd, Balatonöszöd, Siófok.
Trachys puncticollis rectilineata Abeille de Perrin, 1900 - Közép-európai elterjedésú faj, amely szulákféléken szórványosan fordul elő. Balatonföldvár.

Trachys scrobiculatus Kicsenwetter, 1857 . Holomediterrán elterjedésú faj, amely mentaféléken fordul eló, nem túl gyakori. Balatonöszöd, Somogyszob-Baláta-tó, Siófok.

Trachys troglodytes Gyllenhal, 1817 . Euroszibériai elterjedésú faj, amely a füves területeken helyenként nem ritka. Balatonendréd, Balatonöszöd, Kaposfüred.

Trachys troglodytiformis Obenberger, 1918 Nyugat-palearktikus elterjedésú faj, amely madármályván és zilizfajokon fordul clő, ritka. Siófok, Zamárdi.

\section{I. táblázat: A fajok száma genuszok szerint Magyarországon, illetve Somogy megyében}

\begin{tabular}{|c|c|c|c|c|}
\hline Alcsalád & Tribus & Genus & $\begin{array}{c}\text { Fajszám } \\
\text { Magyarországon }\end{array}$ & $\begin{array}{c}\text { Fajszám Somogy } \\
\text { megyében }\end{array}$ \\
\hline Polycestinae & Ptosimini & Ptosima & 1 & 1 \\
\hline \multirow{2}{*}{ Acmaeoderinae } & Acmacoderini & Acmaeodera & I & 1 \\
\hline & & Acmacoderella & 2 & 2 \\
\hline Sphenopterinae & Sphenopterini & Sphenoptera & 5 & 2 \\
\hline \multirow[t]{3}{*}{ Chalcophorinae } & Chalcophorini & Chalcophora & $\mathrm{I}$ & () \\
\hline & Psilopterini & Capnodis & I & 1 \\
\hline & & Aurigena & 1 & 1 \\
\hline \multirow[t]{11}{*}{ Buprestinae } & Dicercini & Dicerca & 5 & 4 \\
\hline & & Poecilonota & 1 & 1 \\
\hline & & Lampra & 3 & 3 \\
\hline & & Palmar & $\mathrm{I}$ & 1 \\
\hline & Buprestini & Eurythyrea & 3 & 1 \\
\hline & & Buprestis & 5 & 2 \\
\hline & Kisanthobiini & Kisanthobia & 1 & () \\
\hline & Melanophilini & Trachypteris & 1 & 1 \\
\hline & & Melanophila & 1 & () \\
\hline & & Phaenops & 3 & 1 \\
\hline & Anthaxiini & Anthaxia & 24 & 18 \\
\hline Chrysobothrinae & Chrysobothrini & Chrysobothrys & 3 & 2 \\
\hline \multirow{5}{*}{ Agrilinae } & Coraebini & Coracbus & 4 & 3 \\
\hline & & Meliboeoides & 1 & () \\
\hline & & Meliboeus & 2 & () \\
\hline & & Nalanda & 1 & 1 \\
\hline & Agrilini & Agrilus & 38 & 25 \\
\hline \multirow[t]{2}{*}{ Cylindromorphinae } & Cylindromorphini & Paracylindromorphus & $\mathrm{I}$ & 1 \\
\hline & & Cylindromorphus & 1 & 1 \\
\hline \multirow[t]{3}{*}{ Trachynae } & Aphanisticini & Aphanisticus & 3 & 2 \\
\hline & Trachyini & Habroloma & 1 & $\mathrm{I}$ \\
\hline & & Trachys & 7 & 6 \\
\hline összesen: & & & 119 & 82 \\
\hline
\end{tabular}




\section{Összefoglalás}

Valamennyi hozzáférhetô múzeumi-gyưjtemény és magán-gyújtemény díszbogár-anyagának feldolgozaása alapján összeállításra került Somogy megye díszbogár faunájának jegyzéke. Az ismert irodalomban nem találtam olyan fajt, amelynek ne lett volna meg valamelyik gyújteményben legalább egy bizonyító példánya.

A megye területéról 82 fajt sikerült kimutatni, a Magyarországon előforduló mintegy 119 faj 68,9\%-át. Meggyőződésem, hogy a kimutatott 82 fajhoz még egy-két faj a közeljövóben Somogy megyéból biztosan eló fog kerülni (például az Agrilus delphinensis, Agrilus subauratus), mivel ezeket a fajokat a megyével közvetlenül határos területeken is fogtuk.

Hogy érzékeltethető legyen, milyen jelentôs szám a 82 faj, összehasonlítás céljából megemlítem, hogy a Hortobágyi Nemzeti Park területéról 22 (Somorja I 983), a Kiskunsági Nemzeti Park területéról 38 (SOMORJAi 1986), a Bükki Nemzeti Park területéról 40 (SomorJAr et ÁDÁm 1996), az Órség területéról 29 díszbogár faj (Muskovirs 1997) került kimutatásra!

Hazánk faunájában ritka fajok is elókerültek Somogy megye területérôl, nevezetesen Fonyódról egy példány Dicerca moesta került elố (in coll. Kanabé Dezsó, dátum nélkül), amelyet Magyarország területén azóta sem találták, ezért valószínú, hogy importált fával behurcolt példány lehetett.

A Palmar festiva hazánk faunájára új fajnak számít. Elsó ízben 1999-ben, a Barcsi borókás területén került elő, és ami örvendetes, az itteni elófordulását 2000-ben további példányok elókerülése is megerósítette. A Palmar festiva nagyon szép, „mutatós”, 6-10 mm hosszú, élénk fémfényü zöld színú faj, amelynek az elóhátán egy-egy sötétibolya, nagyjából kerek folt, és a szárnyfedôkön is hat-nyolc kékesfekete színú, kerek folt van. Feltétlenül minél elóbb védelemre javasoljuk!

\section{Köszönetnyilvánítás}

Köszönetemet fejezem ki Dr. Szél Győzőnek, a Magyar Természettudományi Múzeum Állattára fómúzeologusának, Dr. Horvatovich Sándornak a pécsi Janus Pannonius Múzeum fómúzeologusának, továbbá Gaskó Kálmánnak (Budapest), Dr. Ilniczky Sándornak (Budapest), Juhász János Csabának (Budapest), Dr. Medvegy Mihálynak (Budapest), Muskovics Andrásnak (Tárnok), Rahmé Nikolának (Budapest), Retezár Imrének (Budapest), Rozner Györgynek (Kisberény), Rozner Istvánnak (Budapest) és Szalóky Dezsónek (Budapest), hogy a gyújteményükben lévô példányokat determinálásra rendelkezésemre bocsátották. 


\title{
Irodalom
}

Csík1, E . (1909-1915): Magvaroršág Buprestidái - Rovartani Lapok, 16:161-184, 17:17-22, 18:162-171, 19:135-137, 20:156-159, 22:88-107 pp.

KASZAB, Z. (1940): Die Buprestiden Ungarns, mit Beschreibung neuer Formen (Coleopt.). Fragmenta faunistica Hungarica, 3: $81-116 \mathrm{pp}$.

KUTHY, D. (1896): Buprestidae - in: A Magyar Birodalom Nllatvilága (Fauna Regni Hungariae), III. Arthropoda (Insecta, Colcoptera) - M. K. 'èrmészetudonányi Társulat, Budapest 110-1 14 pp.

MERKL, O. (1998): Data to 46 bectle families (Colcoptera) from the Duna-Dráva National Park, South Hungary. - Dunántúli Dolgozatok Temészetudományi Sorozat 9, 209-232 pp., Pécs

Muskovtrs, J. (1997): Az Örség dlíszbogár faunája (Coleoptera: Buprestidac) - Savaria a Vas megyei múzeumok ćrtesítöje - Szombathely, 24/2: 73-80 pp.

Sর́r, J. ( 1 992): Adatok a Boronka-melléki Tájvédelmi Körzet bogárfaunájáho\% (Coleoptera). - Dunántúli Dolgozatok $(\Lambda)$ Természettudományi Sorozat, 7: 149-161 pp., Kaposvár.

Somorjn, Gy. (1983): 'The species of Buprestidac: (Coleoptera) of the Hortobagy National Park - in Mahunka S. (Ed.): The fauna of the Hortobágy National Park Vol. II, Akadémiai Kiadó, Budapest, 203-204 pp.

SOMORJA, Gy. (1986): Buprestidae of the Kiskunság National Park (Coleoptera: Buprestoidea) in Mahunka S. (Ed.): The fauna of the Kiskuság National Park Vol. I., Akadémiai Kiadó, Budapest, 167-173 pp.

SOMORJA, GY. ET ÁDÁM, L. (1996): The species of Elatcroidea and Buprestoidea (Coleoptera) of the Bükk National Park. - In Mahunka S. (Ed.): The Fauna of the Bükk National Park Vol. II., Hungarian Natural History Museum, Budapest, 271-279 pp.

\section{The jewel beetles of Somogy county (Coleoptera: Buprestidae)}

\section{József Muskovits}

The author summarised the jewel beetle fauna (Coleoptera: Buprestidae) of Somogy county in Southern Hungary. Based on the study of the collections of Hungarian museums and private entomologists, the author recorded $82 \mathrm{spec}-$ imens from the Somogy county, while in Hungary 119 species were found. In the collection of Hungarian Natural History Museum the oldest specimens were collected around 1875.

Only one specimen of Dicerca moesta was collected in Fonyód - we don't know exactly when, it was probably between the I. and II. World War - and since that time nobody has found another specimen in Hungary, so it could have been imported with wood.

Palmar festiva is new for the Hungarian fauna. For the first time it was collected in Darány in 1999, and in the following year we managed to collect further specimens in the same area.

\author{
Author's address: \\ Dr. József Muskovits \\ H-1113 Budapest \\ Tardoskedd u. 9. \\ E-mail:muskovitsj@olajterv.hu
}

